УДК 334:005.35

DOI: https://doi.org/10.37320/2415-3583/10.14

Урусова 3.П.

кандидат економічних наук, доцент, докторант,

Запорізький національний університет

ORCID: https://orcid.org/0000-0001-6776-9058

\title{
МОДЕЛІ КОРПОРАТИВНОЇ СОЦІАЛЬНОЇ ВІДПОВІДАЛЬНОСТІ ПІДПРИЕМСТВ ТА ДОЦІЛЬНІСТЬ ЇХ ВИКОРИСТАННЯ В УМОВАХ ЗМІННОГО СЕРЕДОВИЩА
}

У запропонованій статті автор розглядає досвід корпоративної соиіальної відповідальності бізнесу на начіональному та наднаціональному рівнях. Запропоновано аналіз практики КСВ на рівні національних моделей. Розглянуто та проаналізовано моделі формування корпоративної сочіальної відповідальності в Сполучених Штатах Америки, країнах Свропи, Японії, Китайській Народній Республіці та Украӥні. 3 'ясовано, щзо сьогодні тривають процеси формування моделей КСВ у різних краӥнах світу з урахуванням таких особливостей, як географічне розташування, менталітет, духовна філософія, економічний і політичний розвиток краӥни. Установлено, що на формування моделі КСВ в Україні впливають економічна та політична кризи. Практика різних краӥн може значно відрізнятися, але загальні риси домінують.

Ключові слова: сочіальна відповідальність бізнесу, корпоративна сочіальна відповідальність (КСВ), звіт про $K C B$, ключові показники ефективності, сталий розвиток, охорона навколишнього середовища, дотримання прав людини, толерантність.

Постановка проблеми. Одним із важливих аспектів підвищення соціальної відповідальності бізнесу і підвищення його ефективності є орієнтація на міжнародний досвід, на основі якого Міжнародною організацією роботодавців сформульовано концептуальні підходи до розвитку корпоративної політики. 3 огляду на кризовий стан економіки в країні, відсутність фінансових ресурсів, держава ні теоретично, ні практично не в змозі опанувати кризові ситуації. Вирішення означених проблем можливе тільки у співпраці держави і бізнесу. Бізнес повинен нести повну соціальну відповідальність за кризовий стан в країні і прийняти максимально ефективні дії для виправлення становища. Розроблення рекомендацій щодо подолання дефіциту соціальної відповідальності у суспільстві на грунті опрацювання теоретичних концепцій і практичних моделей КСВ країн світу стосовно до реалій України уявляється надзвичайно важливим і своєчасним питанням.

Аналіз останніх досліджень і публікацій. Аналіз останніх досліджень корпоративної культури привертає все більшу увагу науковців, проте як у теоретичних, так і в практичних підходах можна виявити певні обмеження. Сьогодні проблеми формування корпоративної культури часто зводяться до впровадження іміджевих та розважальних програм, тоді як іiї потенціал може бути розкритий лише за умови її значення у зростанні конкурентних переваг підприємства. Підхід українських учених до рівня (якості) корпоративної культури базується переважно на моделях країн із розвиненим ринком та має яскраво виражений інноваційний аспект. Вагомим внеском у розвиток наукових уявлень про соціальну відповідаль- ність бізнесу стали праці П. Друкера, А. Динкіна, М. Кастельса, Кофі А. Аннана. В Україні цим питанням присвятили свої дослідження такі науковці, як В.М. Жуковська [3], О.П. Мишковська [6], Л.П. Петрашко [8] Н.О. Ткаченко [9] та ін. У працях В.М. Жуковської однією з головних ідей $\epsilon$ те, що підвищення конкурентоспроможності вітчизняного виробництва вимагає не лише зростання його технологічного рівня, залучення інвестицій, а й формування корпоративної культури, гідного стимулювання наполегливої творчої праці керівників і персоналу підприємств щодо вдосконалення інноваційного менеджменту, створення умов для постійного збагачення й оновлення знань, зацікавленості працівників у розробленні та ефективному впровадженні нових проєктів і технологій [13, с. 120-128]. Вивченню світових моделей соціальної відповідальності за різних форм управління присвячено роботу Н.О. Ткаченко [9, с. 102-109].

Незважаючи на велику кількість праць, присвячених дослідженню соціальної відповідальності бізнесу, окрему увагу, на нашу думку, слід приділити вивченню моделей формування соціальної відповідальності бізнесу та проблематиці їх застосування в реаліях української економікополітичної ситуації.

Мета статті полягає в огляді зарубіжного досвіду формування моделей соціальної відповідальності підприємництва. Предметом дослідження $\epsilon$ наукові дискусії українських і зарубіжних учених стосовно вирішення соціальних проблем та розроблення принципів корпоративного управління.

Виклад основного матеріалу. Спектр міжнародних моделей корпоративної соціальної 
відповідальності визначається передусім дилемою: бізнес самостійно визначає міру свого внеску в розвиток суспільства або офіційні та неофіційні інститути виробляють узгодження суспільних інтересів, які потім трансформуються в обов'язкові вимоги до бізнесу.

Для американської моделі КСВ характерне мінімальне втручання в політику КСВ компаній i корпорацій, але при цьому створено такі умови, згідно 3 якими бізнес-організації США прикладають максимум зусиль до створення і реалізації інноваційних стратегій КСВ (зокрема, для компаній, що роблять значний внесок у КСВ, застосовуються пільгові умови оподаткування). 3 метою огляду діяльності компаній США у сфері реалізації принципів КСВ звернемося до компаній-лідерів за даними провідного індексу, який оцінює компанії за ступенем участі в реалізації стратегій KCB, Dow Jones Sustainability Index за 2016 p. [9].

Класичними вважаються американська й європейська моделі КСВ. Але поряд із ними як самостійні розглядають скандинавську, азіатську (Японія і Південна Корея, але окремо - Китай) і змішану моделі. Їм притаманні свої специфічні риси. Відмінності в моделях пов'язані 3 масштабами і спрямованістю соціальної відповідальності бізнесу в різних країнах, ступенем добровільності та регульованості КСВ із боку держави, характером взаємовідносин бізнесу із зовнішніми і внутрішніми стейкхолдерами, рівнем соціальної захищеності персоналу компаній, дотриманням прав і свобод людини та ін. Спостереження показали, що моделі КСВ, які використовуються за низкою ознак, можна поділити на дві групи: відкриті форми і приховані.

Відкрита форма КСВ - лінія поведінки, яка призводить корпорацію до прийняття на себе відповідальності за рішення тих питань, в яких зацікавлене суспільство. Вона передбачає добровільні і самостійно визначені форми поведінки, програми і стратегії корпорації з питань, які приймаються самою корпорацією або іiі стейкхолде- рами як частина їхньої відповідальності перед суспільством.

У монографіï Є.Я. Віттенберга виділено як переваги, так і недоліки американської моделі КСВ (табл. 1) [2].

Виходячи 3 вищенаведеного, можна зробити висновок, що американська модель ще далека від досконалості.

По-іншому складається розвиток стратегій КСВ в Європі. Активне впровадження КСВ бізнес-організацій в Свропі почалося 3 моменту офіційного закріплення іiі положень на Лісабонському європейському саміті в 2000 р. і публікації «Зеленої книги про КСВ» Свропейською Комісією. В об'єднаній Свропі КСВ визначається як «концепція інтеграції турботи про соціальний i екологічний розвиток у бізнес-операціях компаній у взаємодії зі своїми акціонерами і зовнішнім середовищем» [4].

У країнах Свропи робота компаній в напрямі реалізації стратегій КСВ регламентована державою. На організації покладено обов' язки з обов'язкового медичного страхування, забезпечення пенсіями, охорони навколишнього середовища. Усі ці положення закріплені в Міжнародній організації праці, Загальній декларації прав людини, Організації економічного співробітництва і розвитку, рішеннях всесвітніх самітів та ін. [5].

Регулювання КСВ із погляду права здійснюється на трьох рівнях: наднаціональному, національному та місцевому, а основні принципи КСВ закріплені в таких загальноєвропейських документах, як Інтегрована продуктова політика, Десять принципів Глобального договору ООН, Керівні принципи Організації економічного співробітництва і розвитку для багатонаціональних компаній, Стандарт iз соціальної відповідальності ISO 26000, Керівні принципи ООН із питань бізнесу і прав людини, Схема екологічного менеджменту та аудиту.

Європейська модель значно відрізняється від американської передусім роллю держави в системі взаємовідносин із бізнесом. Органи

\section{Переваги та недоліки американської моделі КСВ}

Таблиця 1

\begin{tabular}{|l|l|}
\hline \multicolumn{1}{|c|}{ Переваги моделі КСВ } & \multicolumn{1}{|c|}{ Недоліки моделі КСВ } \\
\hline 1) легка реалізація на практиці & 1) вузьке коло стейкхолдерів, з якими безпосередньо взаємодіє бізнес, що \\
за рахунок професійного розпо- & ускладнює нарощування соціального капіталу компаній; \\
рядження коштами, переданими & 2) практично повна відсутність державного регулювання і контролю прово- \\
корпораціями в соціальні фонди, & кує серйозні порушення з боку корпорацій, коли допускаються обман інвес- \\
які оптимізують ї використання & торів, споживачів, висока експлуатація в зарубіжних країнах та інші нега- \\
в пріоритетних проєктах для кон- & тивні явища; \\
кретних штатів; & 3) на значній частині американських компаній, чиї акції котируються на біржі, \\
2) раціональніст, зумовлена міні- & по суті, відсутні реальні господарі - мажоритарні акціонери (мають контр- \\
мізацією витрат управління КСВ; & ольні або солідні пакети акцій), зацікавлені в позитивному іміджі своєї фірми. \\
3) ліберальність, заснована на & А тимчасові міноритарні акціонери (з невеликим числом акцій), які станов- \\
добровільності компаній і вкрай & лять більшість, переслідують лише фінансовий інтерес і не схильні заохочу- \\
рідкісне втручання держави & вати соціальні інвестиції. \\
\hline
\end{tabular}


державної влади та місцевого самоврядування грають активну роль у законодавчо регульованому процесі розвитку КСВ. Слід звернути увагу на те, що європейська модель КСВ неоднорідна і має деякі відмінності у Центральній Свропі, Великобританії та Скандинавських країнах.

У моделі КСВ у континентальній Європі на відміну від США корпорації більш помітні в питаннях обмеження своєї відповідальності перед суспільством. Європейська модель КСВ не характеризується відкритою лінією поведінки компаній. Навпаки, корпоративна діяльність, як правило, регулюється нормами, стандартами i законами. Однією 3 основних особливостей даної моделі КСВ є державне регулювання.

Розглянемо модель КСВ Великобританії, яка має свої певні особливості. Як відомо, Великобританія займає в світі особливе місце як «Майстерня світу», де Адам Сміт створив знамениту працю «Дослідження про природу i причини багатства народів», а Джеймс Уатт перший винайшов парову машину. Крім того, ця острівна країна географічно не входить у континентальну Свропу. КСВ у Великобританії поєднує елементи американської та континентальної моделей.

У цілому для британської моделі характерні такі ознаки:

- широкий розвиток сектору незалежного консалтингу у сфері КСВ;

- пильна увага фінансового сектору до проєктів у сфері КСВ (тенденція зростання кількості соціально відповідальних інвестиційних фондів);

- підвищений інтерес засобів масової інформації (наприклад, «Таймс» публікує індекси соціальної відповідальності у своєму щотижневому розділі «Профіль компанії»);

- система бізнес-освіти Великобританії однозначно перевершує подібну систему в континентальній Європі за кількістю і різноманітністю навчальних курсів у сфері КСВ;

- активну участь уряду в розвитку КСВ (у Великобританії навіть існує міністерство 3 координації корпоративної соціальної відповідальності);

- принциповим моментом є яскраво виражена ініціативність самого бізнесу в створенні проєктів у сфері КСВ, що, по суті, повністю узгоджується з принципом добровільності.

Шведська модель відрізняється від інших європейських моделей максимальним рівнем соціальної відповідальності. Зокрема, компанія IКЕА є лідером багатьох рейтингів соціально відповідальних компаній. Однак дана модель не завжди може застосовуватися в інших регіонах.

По-перше, більшість шведських компаній, навіть найбільш великих, є сімейними підприємствами, відповідно, в основі вибору об'єкта соціальної відповідальності часто лежать суб'єктивні переваги сім’ї.
По-друге, характерною рисою корпоративної структури шведських компаній є складна ієрархічна структура: сімейна холдингова компанія контролює низку фірм, які, своєю чергою, контролюють наступну групу компаній, i, таким чином, усі стейкхолдери виявляються спочатку учасниками однієї досить закритої групи.

По-третє, Скандинавські країни досить невеликі як за територією, так і за чисельністю, що збільшує можливості «адресного характеру» програм.

Як було зазначено вище, існує й інший підхід до типології моделей КСВ, заснований на ролі держави в регулюванні і підтримки програм КСВ. Дана типологія була вперше запропонована Європейською бізнес-асоціацією:

- партнерська модель (Данія, Фінляндія, Нідерланди, Швеція): стратегія партнерства в усіх сферах, включаючи питання зайнятості;

- модель «бізнес у суспільстві» (Ірландія, Великобританія): політика м'якого втручання 3 метою стимулювати компанії до вирішення державних проблем;

- стійкість і громадянство (Німеччина, Австрія, Бельгія, Франція, Люксембург): соціальний договір з акцентом на сталий розвиток [1].

Соціальна відповідальність корпорації в Японії підтримується культурними традиціями країни. Патерналістська модель грунтується на філософії, згідно з якою «члени виробничого колективу - одна сім'я, а власники компанії - добрі батьки сімейства». Працівник уважається членом такої сім’”̈, а отже, його відповідальність і права виходять далеко за рамки звичайних трудових обов'язків. Своєю чергою, корпорація підтримує його на всьому життєвому шляху: допомагає в придбанні житла, виділяє фінансову допомогу при народженні дітей, а потім їх навчанні, виплачує щедру вихідну допомогу та корпоративні пенсії.

На противагу скандинавській моделі у традиційній японській системі довічного найму всередині фірми «бізнес відповідає за все». Для менеджменту японських підприємств характерні високі морально-етичні принципи, моделі організації виробництва, орієнтовані на випуск високоякісної і безпечної продукції («бережливе виробництво»), охорону навколишнього середовища, сумлінну сплату податків.

В останні десятиліття японська модель трансформується в напрямі, що наближає іiі до принципів європейської та американської систем, посилення активної ролі держави, яка протягом довгого часу брала участь у стратегічному плануванні. Протягом останніх років у соціальній відповідальності Японія набирає обертів, охоплює всю структуру управління в компанії, не обмежуючись внутрішнім спрямуванням [10, с. 102-109].

КСВ активно впроваджується в стратегії бізнесорганізацій не тільки розвинених країн. Звернемося 
до реалізації ініціатив КСВ у Китайській Народній Республіці. Для великих транснаціональних компаній Китаю характерні три суміжні ролі:

1. Вони є легкодоступними об'єктами для державного втручання.

2. Вони є гравцями глобального ринку, серйозно уразливими перед міжнародними вимогами до КСВ.

3. Вони є найбільш помітними і визнаними учасниками КСВ на національних ринках.

Наприклад, Державна комісія КНР 3 нагляду й управління державними активами (SASAC) стверджує, що основна причина, через яку вимоги КСВ пред'являються до великих державних підприємств, полягає у тому, що «показники соціальної відповідальності стали важливим критерієм оцінки підприємств для міжнародного співтовариства». Водночас КСВ допомагає зміцнити «імідж Китаю як відповідальної країни, що розвивається». У цих умовах провідні ТНК Китаю виступають першопрохідцями і подають приклад у сфері КСВ іншим національним компаніям.

Специфікою вітчизняної моделі КСВ є іiі стихійне, непослідовне розповсюдження на добровільній основі серед низки великих компаній. Передусім йдеться про підписантів ГД ООН - таких сьогодні в Україні 149 [7]. За період від дати офіційної презентації ГД ООН в Україні (26.04.2006) у середньому щороку до нього долучалися 23 компанії, що діють на території нашої держави [8, с. 109-115].

Слід зазначити, що в Україні досі відсутні будьякі закони регулювання сфери соціальної відповідальності бізнесу. Це означає, що на державному рівні координації КСВ у нашій країні немає. Ключовою проблемою регулювання КСВ $є$ впровадження та виконання вимог чинного законодавства у сфері соціально відповідальної поведінки бізнесу для формування та розвитку вітчизняної моделі КСВ на засадах стратегічного партнерства влади та бізнесу [8, с. 109-115].

Моделі участі українських компаній у вирішенні суспільно значущих соціально-економічних проблем умовно поділяють на дві групи:

1) моделі соціальних інвестицій (проведення конкурсів, фінансування фондів місцевих спів- товариств, гранти, стипендіальні програми і програми стратегічних інтервенцій, ярмарки некомерційних організацій і соціальних проєктів тощо);

2) комунікативні моделі (громадські ради, координаційні ради із соціального партнерства як постійно діючі майданчики для діалогу з місцевою владою, моніторингу й оцінки впливу компаній на соціальну сферу, соціальна звітність тощо) [3, с. 118-123].

Діалог на тему СВБ в Україні загалом ведеться на рівні окремих проєктів та ініціатив без прив'язки до точних показників, можливості чітко оцінити чи підтвердити досягнутий прогрес. В Україні ще не сформовані інститути всебічної оцінки діяльності компанії, які враховують соціальний, економічний та екологічний вплив їхньої діяльності (як позитивний, так і негативний) та пов'язують такий вплив із національною стратегією сталого розвитку. Безперечним $\epsilon$ той факт, що неможливо розробити уніфіковану концепцію або модель соціальної відповідальності для всіх компаній у цілому. Кожне підприємство має свою специфіку діяльності, географічне розташування, певне фінансове становище та багато інших складників, які впливатимуть на рішення керівництва щодо власної концепції соціальної відповідальності підприємства [6, с. 127-130].

Висновки. Незважаючи на єдине розуміння підходів і принципів КСВ, у кожній країні та регіоні концепція соціальної відповідальності бізнесу має відмінні риси, пов'язані з історією, національними та культурними особливостями, політичним, економічним і соціальним розвитком. Виділяють такі моделі КСВ: американську, європейську, японську (азіатську), Китайської Народної Республіки та України. У світових моделях КСВ виділяють два підходи: корпоративні рішення, засновані на етичних цінностях і спрямовані на задоволення очікувань усіх стейкхолдерів, представляються як необхідні (європейський підхід), так і юридично необов'язкові (американський підхід). В Україні відзначено усвідомлення важливості формування моделі соціальної відповідальності бізнесу, проте її практичне втілення не відповідає політиці досягнення соціального миру, яка задекларована міжнародними стандартами у сфері КСВ.

\section{Список використаних джерел:}

1. Батаева Б.С. Сотрудничество государства и бизнеса для решения социальных проблем : коллективная монография / под ред. Е.Б. Завьяловой. Москва : МГИМО-Университет, 2017. С. 66.

2. Виттенберг Е.Я. Социальная ответственность бизнеса на постсоветском пространстве. Москва : РГГУ, 2011.

3. Жуковська В.М. Соціальні важелі впливу на розвиток підприємств торгівлі. Бізнес-навігатор. 2018. Вип. 11(44). С. 118-123.

4. Костин А.Е. Корпоративная социальная ответственность и устойчивое развитие: мировой опыт и концепция для РФ. Менеджмент в России и за рубежом. 2005. № 3.С. 112-122.

5. Корпоративная социальная ответственность в Европе: что нужно знать предпринимателю, выходящему на европейские рынки. URL : http:// permtpp.ru/upload/iblock/58c/kso.pdf (дата звернення: 16.12.2019).

6. Мишковська О.П Моделі соціальної відповідальності для малого, середнього та великого бізнесу. Наукові праці Чорноморського держсавного університету імені Петра Могили. Серія «Соціологія». 2012. Т. 201. Вип. 189. С. $127-130$. URL : http://nbuv.gov.ua/UJRN/Npchdusoc_2012_201_189_27 (дата звернення: 16.12.2019). 
7. Офіційний сайт мережі ГД ООН в Україні. URL : http:/www.globalcompact.org.ua/howtojoin/benefits (дата звернення: 16.12.2019).

8. Петрашко Л.П. Вітчизняна модель корпоративної соціальної відповідальності: оцінка формування, становлення та розвитку. Ученые записки Крымского инженерно-педагогического университета. 2011. Вып. 30. C. 109-115. URL : http://nbuv.gov.ua/UJRN/VzKipu_2011_30_26 (дата звернення: 16.12.2019).

9. Ткаченко Н.О. Аналіз моделей соціальної відповідальності фармацевтичного бізнесу. Фармацевтичний журнал. 2013. № 1. C. 9-15. URL : http://nbuv.gov.ua/UJRN/pharmazh_2013_1_3 (дата звернення: 16.12.2019).

10. Ткаченко Н.С. Мотивація соціальної відповідальності. Економіка. Менеджмент. Підприємниитво. 2008. Вип. 19(1). С. 102-109.

11. Industry Group Leaders 2016/ RobecoSam .We are sustainability investing. URL : http://www.robecosam.com/en/ sustainability-insights/about-sustainability/corporatesustainability-assessment/industry-group-leaders.jsp (дата звернення: 16.12.2019).

\section{References:}

1. Bataeva, B.S. (2017). Sotrudnichestvo gosudarstva i biznesa dlya resheniya sotsial'nykh problem [State and business cooperation for social problems solving]. Moskva: MGIMO-Universitet. [in Russian]

2. Vittenberg, E.Ya.(2011) Sotsial'naya otvetstvennost'biznesa na postsovetskom prostranstve [Business social responsibility in the post-Soviet period]. Moskow: RGGU. [in Russian]

3. Zhukovsjka, V.M. (2018). Socialjni vazheli vplyvu na rozvytok pidpryjemstv torghivli [Social levers for the development of trade enterprises]. Biznes-navigator - Business-navigator, 11(44), 118-123. [in Ukrainian]

4. Kostin, A.E. (2005). Korporativnaya sotsial'naya otvetstvennost' i ustoychivoe razvitie: mirovoy opyt i kontseptsiya dlya RF [Corporative social responsibility and sustainable development: world experience and concept for RF]. Menedzhment $v$ Rossii i za rubezhom -Management in Russia and abroad, 3, 112-122. [in Russian]

5. Korporativnaya sotsial'naya otvetstvennost' v Evrope: chto nuzhno znat' predprinimatelyu, vykhodyashchemu na evropeyskie rynki [Corporative social responsibility in Europe: what entrepreneurs entering European markets need to know]. (n.d.). permtpp.ru. Retrieved from http:// permtpp.ru/upload/iblock/58c/kso.pdf. (accessed 16 December 2019). [in Russian]

6. Myshkovsjka, O.P. (2012). Modeli socialjnoji vidpovidaljnosti dlja malogho, serednjogho ta velykogho biznesu [Social responsibility models for small, medium and large businesses]. Naukovi praci Chornomorsjkogho derzhavnogho universytetu imeni Petra Moghyly. Ser.: Sociologhija. - Scientific works of Chornomorsk state university named after Petro Mohyla. Ser.: Sociology, v. 189, 127-130. Retrieved from http://nbuv.gov.ua/UJRN/Npchdusoc_2012_201_189_27. [in Ukrainian] (accessed 16 December 2019).

7. Sait merezhi GhD OON v Ukrajini [Site of GhD OON net in Ukraine]. (n.d.). globalcompact.org.ua. Retrieved from http://www.globalcompact.org.ua/ howtojoin/benefits. [in Ukrainian] (accessed 16 December 2019).

8. Petrashko, L.P. (2011). Vitchyznjana modelj korporatyvnoji socialjnoji vidpovidaljnosti: ocinka formuvannja, stanovlennja ta rozvytku [Domestic corporate social responsibility model: Assessment of formation, establishment and development]. Uchenye zapiski Krymskogo inzhenerno-pedagogicheskogo universiteta - Researchers' notes from the Crimean Institute of Engineering and Pedagogical, v. 30, 109-115. Retrieved from http://nbuv.gov.ua/UJRN/VzKipu_2011_30_26. (accessed 16 December 2019) [in Ukrainian]

9. Tkachenko, N.O. (2013). Analiz modelej socialjnoji vidpovidaljnosti farmacevtychnogho biznesu. [Analysis of social responsibility models of pharmaceutical business]. Farmacevtychnyj zhurnal - Pharmaceutical journal, 1, 9-15. Retrieved from http://nbuv.gov.ua/UJRN/pharmazh 2013 1 3. (accessed 16 December 2019). [in Ukrainian]

10. Tkachenko, N.Je. (2008). Motyvacija socialjnoji vidpovidaljnosti [Motivation of social responsibility]. Ekonomika. Menedzhment. Pidpryjemnyctvo - Economics. Management. Entrepreneurship, v. 19(1), 102-109. [in Ukrainian]

11. Industry Group Leaders 2016/ RobecoSam. We are sustainability investing. (n.d.). robecosam.com. Retrieved from http://www.robecosam.com/en/sustainability-insights/about-sustainability/corporatesustainability-assessment/industry-groupleaders.jsp. (accessed 16 December 2019). [in English] 
Urusova Zinaida

Zaporizhzhia National University

\section{CORPORATE SOCIAL RESPONSIBILITY MODELS OF ENTERPRISES AND THEIR APPROPRIATENESS IN A CHANGING ENVIRONMENT}

Ideas of social justice, equality and responsibility have been gaining popularity in recent continents. In the proposed article the author explores the experience of corporate social responsibility of business both at national and supranational level. An analysis of CSR practices at the level of national models is also offered. The study examines and analyzes models of corporate social responsibility formation in the United States, Europe, Japan, the People's Republic of China and Ukraine. To date, corporate social responsibility for business plays an important role in supporting society in social, economic and environmental spheres. The CSR concept assumes that the rational interests of business are directed not only at maximizing profits, but also at improving their environment (political, social, economic) through voluntary investment in appropriate institutions. Each management model provides different opportunities in terms of implementing the principles of social responsibility. It is found that the processes of CSR model formation in different countries of the world today take into account such features as geographical position, mentality, spiritual philosophy, economic and political development of the country. The basic principles of CSR functioning are covered. It is established that the formation of the CSR model in Ukraine is affected by economic and political crises. The current stage of economic development requires business structures to work closely with all stakeholders to find mutually beneficial solutions and effectively implement them. In these circumstances, corporate social responsibility (CSR) becomes one of the most important institutions of the developed economy. The practice of different countries may vary greatly, but the general features dominate. This is linked both to the general culture and history, and to active public policy at national and supranational levels. The success of CSR implementation in Ukraine will depend on how effectively the state, business and society can learn the positive and negative lessons of foreign models, as well as extrapolate the mechanisms of CSR implementation into Ukrainian realities.

Key words: Corporate Social Responsibility (CSR), Corporate Social Responsibility (CSR), CSR Report, Key Performance Indicators, Sustainable Development, Environmental Protection, Human Rights, Tolerance.

JEL classification: A14, D2, M21, O1. 